\title{
Enterprise Resource Planning of Procurement Process with SAP MM Module
}

\author{
Dhuhadmya Anggiya Kirana $^{1 *}$, Muhardi Saputra ${ }^{2}$, Warih Puspitasari ${ }^{3}$ \\ 1,2,3 Industrial Engineering Department, School of Industrial Engineering, Telkom University \\ Jl. Telekomunikasi No.1, Bandung, 40257 INDONESIA \\ *anggykrn@student.telkomuniversity.ac.id
}

\section{ARTICLE INFO}

\section{Article history:}

Received 11 January 2021

Accepted 28 January 2021

Published 31 January 2021

\begin{abstract}
IN ENGLISH
PT XYZ is one of the mining companies in Indonesia that has many subsidiaries. From user interviews, there's a problem in carrying out daily transactions in the procurement process. There is no integration between departments when using existing applications, lots of inappropriate data, and some documents with missing files. Thus causing data not on time and working time. The analysis was carried out using a conceptual model to see the problems and needs in PT XYZ. ERP system needs to be implemented, coordinating the company's business processes and reset the company's infrastructure and standardization. The ERP system in the material management module will be implemented using the ASAP method because this method is tailored to the company. The ASAP method can describe implementation activities to support project management and data migration faster than other implementation methods.
\end{abstract}

Keywords:

ERP, SAP, Accelerated SAP

Method, Material

Management, Procurement.

\section{Introduction}

Increasingly rapid technology increases competitiveness in the scope of business and companies. Companies are competing to get the best system used in their companies to make existing transactions and business processes easily carried out, computer-based, have adequate security and are mutually integrated. There has been a lot of software that provides companies' systems from small start-ups to other large companies. Companies must choose the best software from existing software that helps them run the company's business processes well every day to continue to grow and compete with other companies. [1]

ERP has a system that functions to integrate business processes and functions in the company. The resulting system will also be tailored to its needs and can increase existing operational activities' effectiveness. [2] ERP or Enterprise Resource Planning is integrated software with all aspects of business functions in a company and will support its business processes. ERP itself can manage existing resources in the company by using integrated information technology.

One of the software used to implement ERP is SAP. SAP or System Application and Product itself is software made for ERP implementation, whose function is to help plan and carry out company activities. [3] SAP is a software best practice. As the largest software company in Europe, SAP can integrate existing business activities in the company and provide benefits for the company's success. SAP is also an Enterprise Resources Planning (ERP) software, an IT and management tool to help companies plan and carry out various daily activities. SAP also provides many modules to implement. These modules have different functions and purposes and will later be integrated with others. [4] SAP itself has several modules, consist of sales and distribution (SD), material management (MM), production planning (PP), quality management $(\mathrm{QM})$, plant maintenance $(\mathrm{PM})$, human resource management (HCM), financial accounting (FI), controlling (CO), asset management (AS) and project system (PS). [7] 
SAP, which has many modules, can also be implemented according to the needs of the company. One of the modules is the material management module. Material management is a module used for warehouse management in the procurement process. Procurement of goods itself is an essential process in a company that must be carried out and recorded carefully, accurately, and in real-time to ensure no errors in the activities carried out. [8] The material management module will also be connected with other divisions, including the finance division for payments to vendors.

PT XYZ is one of the major companies engaged in mining and has many subsidiaries spread across several Indonesian cities. PT XYZ is a mining company and is a large company that carries out transactions using several existing in-house applications. Still, as long as it uses more than one application in each department, transactions will not be integrated, which can cause many documents containing unmatched data. These documents are late arriving at the related departments between one department and another. That way, transactions are carried out late and take a lot of time to recap the data if they are not suitable.

PT XYZ wants to develop a system that can carry out daily transactions more effortless, and there are no incompatible data or documents and late documents. PT XYZ also wants transactions carried out every day to be real-time transactions so that each subsidiary can see transactions and stock items from each warehouse. That way, it will be easier later to get interdepartmental data if there are other related departments.

Therefore we need a system that can make transactions in real-time so that transactions can run well and integrated between modules in the Enterprise Resource Planning (ERP) system, namely using the SAP Material Management module in the procurement process. The researcher made an ERP system design using the SAP material management module in the procurement section using the accelerated SAP (ASAP) method. [5] The ASAP method is one of the methods used as an SAP implementation guide, aiming to streamline management planning during SAP implementation. Additionally, using the ASAP method can optimize business processes developed by SAP. The ASAP method has five stages, including project preparation, blueprint, realization, final preparation, and go-live. This research will only carry out until the realization stage.

\section{Basic Theory}

\subsection{Enterprise Resource Planning (ERP)}

ERP is a system used for management in business in the company based on the effectiveness of the resources used to increase the efficiency of existing processes in the company. ERP provides some benefits for companies, such as reduce processing time, speed up information, and carry out the company's activities in real-time. ERP can reduce costs and can increase revenue and market share. In this way, an ERP system's existence can increase company value, which will make it easier for companies because of its integrated modules. ERP is beneficial for companies to grow. [13]

ERP includes the following module.
a. Purchase
b. Human Resource Management (HRM)
c. Customer Relationship Management (CRM)
d. Inventory
e. Warehouse
f. Finance

\subsection{System Application and Product (SAP)}

SAP is an ERP software. It has integrated modules and is designed so that data can be used by various parties who have access, and the process is by those in the company. SAP is known for being one of the ERPs that provide the best practices from well-known companies globally, thus guiding companies that implement them on how best practices should be carried out so that the company's performance increases with SAP ERP implementation. SAP can plan various day-to-day company activities. SAP provides so many kinds of modules that can be integrated with others in carrying out company activities. The modules in SAP are as follows. [12]
a. SD-Sales \& Distribution
b. MM-Materials Management
c. PP-Production Planning
d. QM-Quality Management
e. PM-Plant Maintenance
f. HR-Human Resources Management
g. FI-Financial Accounting
h. CO-Controlling
i. AM-Asset Management
j. PS-Project System 


\subsection{Material Management Module}

Material management is one of the SAP modules to support material management activities, inventory operations, procurement of goods, demand for goods, purchases, receipt of goods, and payments to vendors in a company. The materials in material management are ready-to-sell items, semi-finished materials, and raw materials. [14] The primary function of the SAP MM module, namely. [8]

a. Material Requirement Planning

Monitor existing stock and make proposal orders to the purchasing department based on the requirements planning method.

b. Purchasing

Optimize the purchasing or procurement process. The process carried out by purchasing is making purchase requests (purchase requisitions), making requests for quotations, quotations if necessary, and creating purchase orders.

c. Inventory Management

Inventory management was carried out to make stock changes in the warehouse, increasing inventory and reducing inventory in the warehouse. The transactions carried out are as follows.

1. Goods Receipts

2. Return Deliveries

3. Planned and Unplanned Stock Withdrawals

4. Stock Transfers

5. Reservations

6. Stock Adjustment

d. Invoice Verification

Check invoices from vendors for purchases of goods that have been made, whether the purchases of goods with invoices are appropriate or not. If proper, payment is made to the vendor; otherwise, the bill will be rejected.

e. Material Valuation

Determine the company's value and price with SAP MM standards, namely LIFO, FIFO, and lowest value determination.

f. Logistics Information System

The decision making for the transaction strategy is processed daily through analyzed data and variables. Includes Inventory Controlling (INVCO) and Purchasing Information System (PURCHIS).

\subsection{Procurement}

Procurement or procurement of goods is a process to obtain goods and services needed by the company, from the initial request for goods to payment of invoice verification. The procurement process carried out is as follows. [11]

a. Purchase requisition,

b. Selecting vendor,

c. purchase order,

d. Goods Receipt,

e. Invoice verification,

f. Payment.

\subsection{Metode Accelerated SAP (ASAP)}

Accelerated SAP is one of the methods recommended by SAP to be implemented in companies because the ASAP method can help and ensure the results of implementation provide good results efficiently and effectively for the company. The ASAP method has five stages as follows. [15]

a. Project Preparation

Focus on the project to determine the objectives, scope, timeline of implementation activities, and the project team involved in this implementation.

b. Business Blueprint

Documenting the company's ongoing business processes and target business processes after using SAP so that the company's implementation process runs according to the company's needs.

c. Realization

Perform configuration on the system by the agreed blueprint design.

d. Final Presentation

In the final presentation phase, SAP system training will be conducted for users in the company.

e. Go Live

Implement systems in the company and carry out periodic maintenance in the company. 


\section{Research Method}

\subsection{Conceptual Model}



Fig. 1 - Conceptual Model

The author uses a conceptual model to determine problems based on the environment and lead to technology. The appropriate needs for PT XYZ are defined in the research section. Some knowledge includes concepts and methods are required to support the research. The conceptual model is a framework for building existing theories and dealing with the factors that have been identified as a problem. [9] The conceptual model in Figure 1 on designing an ERP system using the SAP material management module using the accelerated SAP (ASAP) method at PT XYZ can be concluded as follows.

1. Environment

Based on the interview, the problem at PT XYZ was the lack of technology to reduce errors during recording and procuring goods. PT XYZ needs a system that can handle movement data in real-time, transparent (can be seen between subsidiary warehouses), and integrated with other subsidiaries' warehouses. This problem can be implemented in the material management module in the procurement section, which will later play an important role.

\section{Research}

Researchers made an ERP system development plan using the concept of Enterprise Resource Planning and the Material Management module in the procurement process. Evaluation using User Acceptance Testing (UAT). UAT is a testing process carried out by users at PT XYZ after the program has been created, and transactions can be made during the testing process following existing business processes in the company and the company's needs.

3. Basic Knowledge

The basic knowledge used for implementing the ERP system at PT XYZ is using the document study methodology, which is collecting the necessary data and the SAP methodology, namely Accelerated SAP (ASAP).

\subsection{Systematic Research}

In systematic research, the stages in the accelerated SAP (ASAP) method are described as a method used for implementing the ERP system, namely project preparation, blueprint, realization, final presentation, and go-live and support. However, this research will only be carried out until the realization stages. The ASAP method itself is an implementation method recommended by SAP because the ASAP method itself is a method that has implementation project guidelines and has efficient business management. [6] 




Fig. 2 - Systematic Research

The following is an explanation of Figure 2 regarding the research systematics:

1. Project Preparation

a. Project Planning

Identify the background of the problem, and the purpose of this activity is to determine the limits that will be carried out in the Material Management Module ERP system development project.

b. Implementation Strategy

Determine and clarify the scope of SAP implementation and discuss the organization that is in the project and the allocation of resources in it.

\section{c. Kick-Off}

Make a timeline regarding ERP system implementation using the SAP application in the Material Management Module in the Procurement process section.

d. Technical Requirement

Describe requirements from all aspects of implementing the Material Management Module in the SAP application.

e. Quality Check

Ensure each current stage suitability with planning and conducting consultations with supervisors and the Material Management section of PT XYZ.

\section{Business Blueprint}

\section{a. Business Blueprint}

Make the results from the data obtained into a blueprint document.

b. Business Process Analysis

Analyze existing business processes (As Is) to match the target business process (To Be).

c. GAP Analysis

Creating a GAP Analysis based on existing business processes and targeting business processes following PT XYZ's needs.

d. Business Process Definition

Map the company's business processes based on GAP Analysis into the SAP application to suit PT XYZ's needs.

e. Quality Check

Checks on each activity that is already running as planned.

\section{Realization}

a. Configuration

Configure according to the business processes defined earlier in the Material Management Module. 
b. Develop Program

Perform development on the program if needed, but this stage will not be carried out.

\section{Final Presentation}

a. Integration Testing

Integration tests on the Material Management Module will ensure that the SAP application is appropriate and run properly. However, this stage will not be carried out.

b. User Acceptance Testing

UAT is a testing process carried out by the end-user, who will then directly interact using the system that has been created. [10] The UAT of Material Management Module by PT XYZ users ensures the results and documents test results that prove that the SAP implementation is as requested. However, this stage is not carried out.

c. Migration Data

Perform data migration, but this stage is not performed.

\section{Go-Live and Support}

a. Production Support

Perform production support, but this stage is not performed.

b. Production End

Perform production end, but this stage is not performed.

\subsection{Problem Solving Systematics}

Problem-solving systematics are designed before implementation at PT XYZ to obtain relevant results and solve PT $\mathrm{XYZ}$ problems following the agreed problem systematics. The following is a systematic flow of problem-solving for implementing the material management module SAP at PT XYZ.

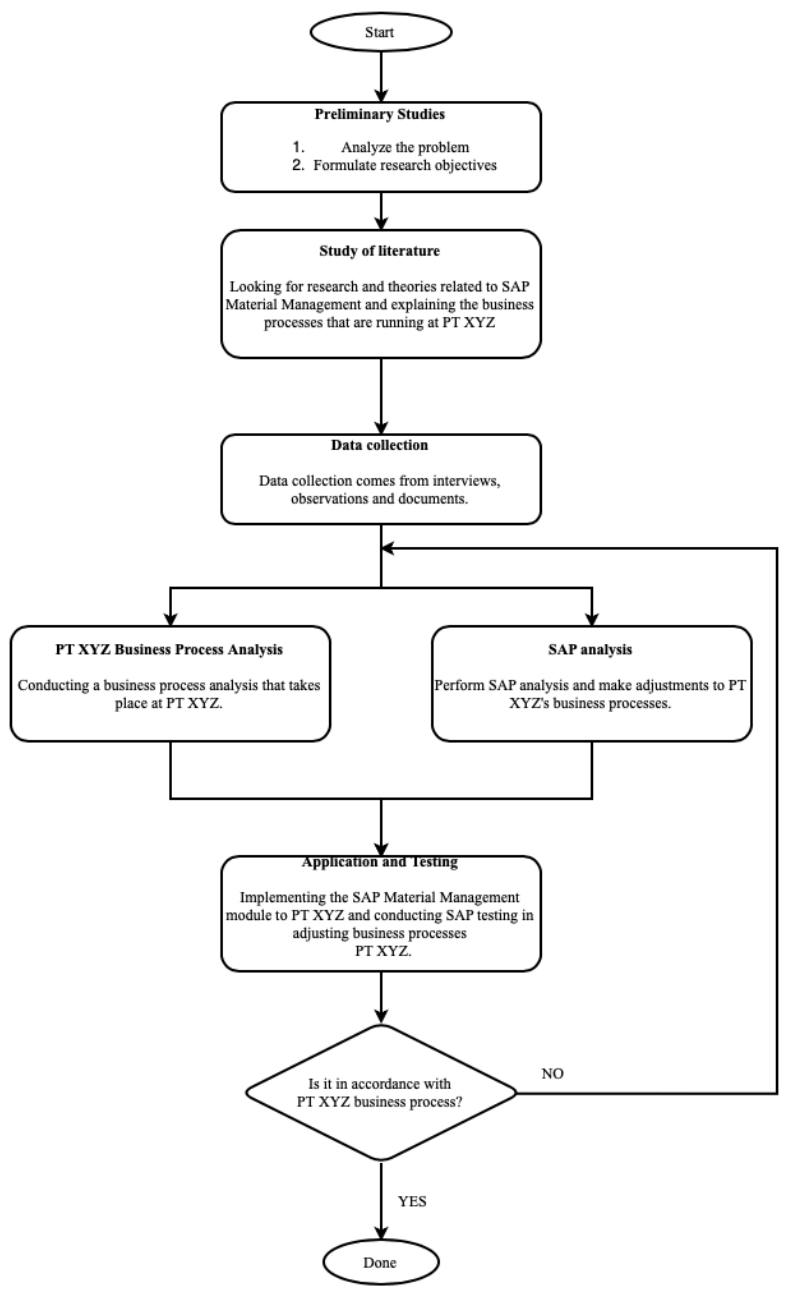

Fig. 3 - Problem-Solving Flow 
Here is an explanation of Figure 3 Problem-solving Flow.

1. Preliminary Studies

In the preliminary study phase, the analysis of a PT XYZ problem will be carried out, especially the procurement process running there. This phase will be carried out by observing the business process and the course of transaction activities there, looking at the integration between divisions, data input processes, purchasing goods, receiving goods at the warehouse until later verification of payments. After conducting the analysis, a discussion of the analysis results will be carried out with other officials and a team of other consultants to identify what is needed and formulate research objectives.

\title{
2. Literature Studies
}

Literature studies are carried out by looking for discussions related to topics or theories appropriate to the implementation of SAP material management in the procurement process. Search can be from journals or books that discuss this so that later you can have information related to the module before designing it according to the existing problems. This literature study will collect data and information, especially in the procurement process section, so that PT XYZ implementation can be carried out following the workflow and data that have been made.

\section{Data Collection}

This data collection activity is carried out to fulfill the files that need to be made for implementation, namely the blueprint document. Which later, this data collection includes data that supports research, namely, general company data, running business process flow, data on purchasing goods, stock of goods, and others at PT XYZ. Data collection can be done by interviewing related parties, observing, and identifying supporting documents.

\section{Business Process Analysis PT XYZ}

Conduct analysis of ongoing business processes at PT XYZ, analyze as-is business processes in PT XYZ on procurement processes, and design business processes to-be after SAP implementation at PT XYZ. Some adjustments will be made after SAP implementation.

\section{SAP Analysis}

SAP analysis for the procurement process, namely the Material Management module with what transactions are carried out at PT XYZ and what transactions are required by PT XYZ to be implemented into SAP.

\section{Implementation and Testing}

After the implementation process is complete, user acceptance testing (UAT) will be carried out, especially in the material management section, to check whether the SAP system is appropriate or still need to be adjusted accordingly at PT XYZ.

\section{Check the conformity of SAP implementation with PT XYZ's Business Process}

In this process, checking the conformity of SAP with the PT XYZ business process (if it is appropriate), then the problem solving can be completed. However, if it is not suitable, it can be repeated from the PT XYZ business process analysis process and SAP analysis, then it is obtained that changes are made to the program that has been made in SAP to match those of PT XYZ.

\section{Analysis Results}

This section analyzes the existing procurement process in PT XYZ, using the FIT GAP analysis according to table 1, FIT GAP ANALYSIS. After that, the business process targeting of the procurement was made for PT XYZ after SAP implementation.

\subsection{Analysis FIT GAP}

\author{
Information \\ $\mathrm{N}$ : needs are not met. \\ P: half of the needs met. \\ F: needs are fully met.
}


TABLE 1 - FIT GAP ANALYSIS

\begin{tabular}{|c|c|c|c|c|}
\hline No & $\begin{array}{l}\text { EXISTING } \\
\text { CONDITION }\end{array}$ & Needs & Fulfillment & Solution \\
\hline 1 & $\begin{array}{l}\text { Purchase } \\
\text { requisition } \\
\text { process }\end{array}$ & $\begin{array}{l}\text { A system integrated with } \\
\text { the warehouse and a } \\
\text { transparent system is } \\
\text { needed so that stock data in } \\
\text { the warehouse can be seen } \\
\text { by other parts, especially in } \\
\text { the procurement section. }\end{array}$ & $\mathrm{F}$ & $\begin{array}{l}\text { SAP will make it easier for } \\
\text { each section or department } \\
\text { so that the data can be } \\
\text { seen by the authorities and } \\
\text { can be documented in real- } \\
\text { time. }\end{array}$ \\
\hline 2 & $\begin{array}{l}\text { Selecting the } \\
\text { vendor process }\end{array}$ & $\begin{array}{l}\text { It takes a system that can } \\
\text { store vendor data in } \\
\text { collaboration with PT XYZ }\end{array}$ & $\mathrm{F}$ & $\begin{array}{l}\text { SAP will store data on } \\
\text { vendors who have } \\
\text { collaborated with PT XYZ } \\
\text { to be easily used during } \\
\text { transactions. }\end{array}$ \\
\hline 3 & $\begin{array}{l}\text { Purchase order } \\
\text { process }\end{array}$ & $\begin{array}{l}\text { It takes a system that can } \\
\text { document in real-time and } \\
\text { can be integrated by } \\
\text { existing activities in } \\
\text { purchasing goods. You also } \\
\text { need a purchase order form }\end{array}$ & $\mathrm{F}$ & $\begin{array}{l}\text { Create a purchase order } \\
\text { that can refer to a purchase } \\
\text { document. Later a } \\
\text { purchase order form will } \\
\text { be formed and } \\
\text { documented in real-time } \\
\text { the PO document and the } \\
\text { purchase reference } \\
\text { document. }\end{array}$ \\
\hline 4 & Goods Receipt & $\begin{array}{l}\text { Document goods receipt in } \\
\text { real-time. }\end{array}$ & $\mathrm{F}$ & $\begin{array}{l}\text { A goods receipt form will } \\
\text { be formed to document } \\
\text { whether the goods were } \\
\text { received or not received } \\
\text { because they are not } \\
\text { suitable. }\end{array}$ \\
\hline 5 & Payment process & $\begin{array}{l}\text { Document } \\
\text { payment } \\
\text { activities and can be } \\
\text { integrated with the } \\
\text { purchasing and finance } \\
\text { department. }\end{array}$ & $\mathrm{F}$ & $\begin{array}{l}\text { Will be integrated bill } \\
\text { payments from the } \\
\text { purchase to be paid by the } \\
\text { finance department. }\end{array}$ \\
\hline
\end{tabular}




\subsection{Target Business Process for Procurement of Goods}

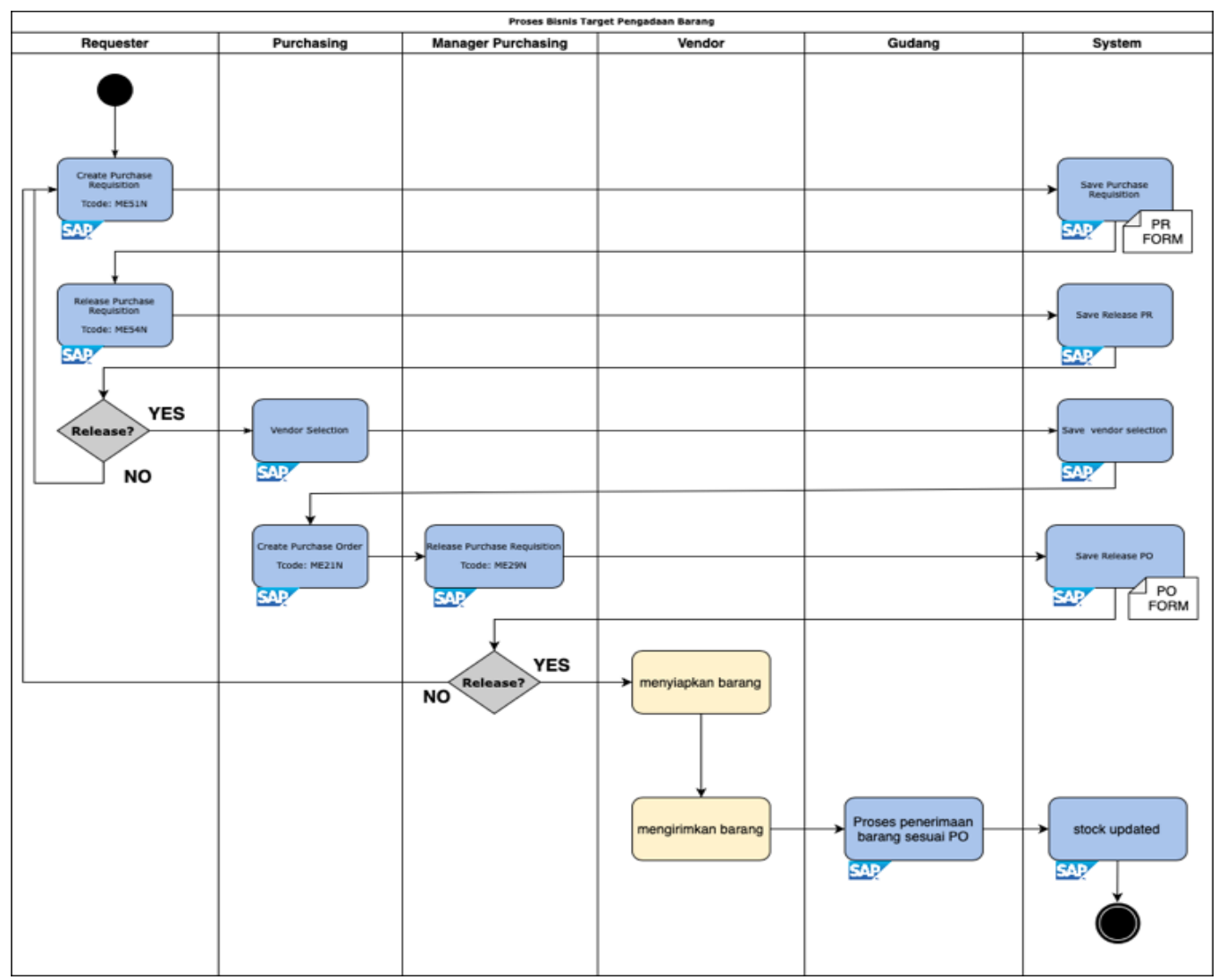

Fig. 4 - Procurement Business Target Process

\section{Conclusion}

The conclusion of this study is the ERP system design using SAP software in the material management module of the procurement process using the ASAP method, which results from the PT XYZ needs analysis. In this way, it can be used to solve the problems in PT XYZ. Within SAP, PT XYZ can easily carry out integrated procurement activities and generate the data in real-time and transparent, seen between other subsidiaries or other company codes. With the SAP system, PT XYZ can see the procurement process results because the data is managed in realtime and automatically documented in SAP and can be seen anytime the procurement history has been made.

This research's limitation is that this research only reaches the design for SAP implementation or only reaches the stage of realization in the ASAP method. Suggestions for further research can continue this implementation process until the go-live and support stages.

\section{Disclaimer}

The authors whose names are written certify that they have no conflict of interest.

\section{References}

[1] R. A. Hidayat, S. Rahayu och A. Nurbaiti, "Faktor-faktor Penentu Keberhasilan Implementasi Enterprise Resource Planning UKM di Bandung," 2o17.

[2] M. H. Irfani, "ERP (ENTERPRISE RESOURCE PLANNING) DAN ASPEK-ASPEK PENTING DALAM PENERAPANNYA," 2017.

[3] R. Maulidina, N. A. Rizki och R. S. Dewi, "Perencanaan dan Implementasi SAP pada PT XYZ dengan Menggunakan Metode Accelerated SAP (ASAP)," Perencanaan dan Implementasi SAP pada PT XYZ dengan Menggunakan Metode Accelerated SAP (ASAP), 2020.

[4] Y. Priyandari, C. A. W., A. Mas'ud och T. S., "Penerapan System Application Product in Data Processing 
(SAP) pada Modul Material Management-Procurement PT. MAK," Seminar Internasional dan Konferensi Nasional IDEC, p. 427, 2016.

[5] W. Hartiningsih, MPLEMENTASI ERP SAP HCM TIME MANAGEMENT POSITIVE MENGGUNAKAN ACCELERATED SAP (ASAP) METHODOLOGY, 2019.

[6] S. A. Gunawan, PERANCANGAN SISTEM ENTERPRISE RESOURCE PLANNING DENGAN SAP MODUL PERFORMANCE MANAGEMENT MENGGUNAKAN METODOLOGI ASAP PADA PT. BURSA EFEK INDONESIA, Bandung: Universitas Telkom, S1 Sistem Informasi, 2018.

[7] K. R. Sungkono, R. Sarno, A. J. Ulhaq, M. Taufiqulsa'di, I. N. KurniaSari och Z. Z. Dinanto, Pembentukan dan Penerapan Enterprise Resource Planning (ERP) pada UMKM (Usaha Kecil Menengah) Toko Budi dan M-Bisy Mart, 2019.

[8] M. Adi, Evaluation Implementation SAP Materials Management Using Balanced Scorecard (Case Study: PT. Greenfields Indonesia), Bandung, 2015.

[9] E. Barlian, METODOLOGI PENELITIAN KUALITATIF \& KUANTITATIF, PADANG: SUKABINA PRESS, 2016.

[10] P. M. D. Prabowo och B. H. Prasetyo, "Penerapan System Application Product in Data Processing (SAP) pada Modul Material Management-Procurement PT. MAK," Seminar Internasional dan Konferensi Nasional IDEC, p. 427, 2016.," Jurnal Informatika Universitas Pamulang, vol. 5, 2020.

[11] S. F. Wijaya och Y. Handoyono, ”Evaluasi Implementasi SAP... (Santo Fernandi Wijaya; Yustina Handoyono) 407EVALUASI IMPLEMENTASI SAP MODUL MATERIAL MANAGEMENT: STUDI KASUS PADA PT BUMITAMA GUNAJAYA AGRO,” ComTech, vol. 3, pp. 407-420, 2012.

[12] D. K. WIjaya och A. Sadjiarto, "IMPLEMENTASI MODUL MATERIAL MANAGEMENT DAN MODUL FINANCE SAP PADA ENTERPRISE CENTRAL COMPONENT SIKLUS PEMBELIAN DI PT "X"," TAX \& ACCOUNTING REVIEW, vol. 4, 2014.

[13] M. S. Ramadhan, "PENERAPAN SISTEM PURCHASE MANAGEMENT MENGGUNAKAN OPENERPDENGAN METODE RAPID APPLICATION DEVELOPMENT(STUDI KASUS : PT GENTA TRIKARYA)," Open Library Telkom University, 2015.

[14] F. A. Rahadi, "PERANCANGAN MODEL SISTEM ENTERPRISE ASSET MANAGEMENT MODUL MATERIAL MANAGEMENT (MM) BERBASIS SAP S/4 HANA PADA BISNIS SEKTOR TRANSPORTASI (STUDI KASUS DI PT XYZ),” 2019.

[15] S. Rahayu, "PENGEMBANGAN SISTEM GREEN ERP MODUL WAREHOUSE BERBASIS ODOO DI INDUSTRI PENYAMAKAN KULIT DENGAN MENGGUNAKAN METODE ASAP (STUDI KASUS: PT.ELCO)," 2019. 